\title{
Effect of dexfenfluramine on gastric emptying of a mixed solid-liquid meal in obese subjects
}

\author{
BY MICHAEL HOROWITZ, ANNE MADDOX, JUDITH WISHART, \\ JANE VERNON-ROBERTS, BARRY CHATTERTON AND DAVID SHEARMAN \\ Departments of Medicine and Nuclear Medicine, Royal Adelaide Hospital, North Terrace, Adelaide, \\ South Australia 5000, Australia
}

(Received 10 July 1989 - Accepted 4 November 1989)

\begin{abstract}
Recent studies suggest that dexfenfluramine ( $D$-fenfluramine), because of its pure serotonergic effect, may be a more potent anti-obesity agent, associated with fewer side-effects than the racemate DLfenfluramine. The effect of dexfenfluramine on gastric emptying of a mixed solid and liquid meal was assessed with a double-isotope scintigraphic technique in eleven obese patients. Each subject took a placebo capsule on the morning and evening of the day before, and on the morning of the first gastric emptying measurement. Dexfenfluramine was then taken at a dose of $15 \mathrm{mg}$ twice daily and gastric emptying measurements were performed at 5 and at $29 \mathrm{~d}$ after the initiation of active treatment. Dexfenfluramine significantly slowed gastric emptying of the solid meal at both 5 and $29 \mathrm{~d}$ when compared with the placebo $(P<0.05)$ and also delayed emptying of solid food from the proximal stomach $(P<0.01)$, but no significant effect on liquid emptying was observed. No significant side-effects were reported and there was a marginal weight loss $(P<0.005)$ during treatment. We conclude that inhibition of gastric emptying may contribute to the efficacy of dexfenfluramine in the treatment of obesity.
\end{abstract}

Dexfenfluramine: Gastric emptying: Obesity

It has been postulated that the control of appetite is mediated partly through the rate of gastric emptying, and slowing of gastric emptying has been suggested as a means of producing a therapeutic decrease in food intake (Gibbs \& Smith, 1978; Booth et al. 1986). The efficacy of DL-fenfluramine in the treatment of overweight has been thought to be mediated largely by central serotonergic mechanisms (Blundell \& Leshem, 1974), but several workers have demonstrated that DL-fenfluramine inhibits gastric emptying of solid and liquid meals in animals (LeDouarec et al. 1966; Davies et al. 1983; Booth et al. 1986; Robinson et al. 1986; Rowland \& Carlton, 1984, 1986a,b,c), and in a recent study from our group administration of a single oral dose of DL-fenfluramine (40 $\mathrm{mg})$ to obese humans slowed gastric emptying of a solid meal (Horowitz et al. 1985). These results suggest that the decreased meal size and prolonged inter-meal interval, which are the characteristic behavioural effects of fenfluramine (Innes et al. 1977; Stunkard, 1981), might be directly linked to gastric slowing (Booth et al. 1986; Rowland \& Carlton, 1986 b). The observations that in the rat, tolerance to the inhibitory effect of DL-fenfluramine on gastric emptying develops rapidly and in a time-course which closely matches tolerance to the anorectic effects of the drug (Rowland \& Carlton, 1984, 1986 b), and in the rhesus monkey that the anorectic efficacy of DL-fenfluramine is closely related to the extent of gastric slowing (Robinson et al. 1986) are consistent with this hypothesis. No studies have, however, assessed the effects of prolonged administration of fenfluramine on gastric emptying in humans.

The $\mathrm{D}$ - and $\mathrm{L}$ - enantiomers of DL-fenfuramine and their metabolites $\mathrm{D}$ - and Lnorfenfluramine have distinguishable biological actions, but until recently the majority of 
behavioural studies have been conducted using the DL, or racemic mixture. At therapeutic dosage, dexfenfluramine (D-fenfluramine) is a potent and selective serotonergic agonist, by releasing and inhibiting the neuronal re-uptake of serotonin (Garattini et al. 1979, 1987), while L-fenfluramine is a less potent serotonergic agonist, and in addition has antidopaminergic properties (Consolo et al. 1980; Garattini et al. 1987). In animals the effects of dexfenfluramine on food intake are considerably greater than L-fenfluramine (Garattini et al. 1979; Hirsch et al. 1982). Dexfenfluramine is also more potent than Lfenfluramine in retarding gastric emptying in the rat (LeDouarec et al. 1966). These observations suggest that the major action of DL-fenfluramine on food intake is predominantly via the D-isomer, or its metabolite D-norfenfluramine, and provide a rationale for the use of dexfenfluramine alone in the treatment of obesity. Recent studies have now confirmed that dexfenfluramine induces sustained weight loss in obese humans, with a low prevalence of side effects (Finer et al. 1985, 1987; Guy-Grand et al. 1989).

We have now assessed the effect of acute $(5 \mathrm{~d})$ and prolonged $(29 \mathrm{~d})$ administration of dexfenfluramine on gastric emptying in obese human subjects and report for the first time a sustained action of this drug on gastric motility.

\section{SUBJECTS AND METHODS}

The studies were performed on eleven randomly selected obese patients (two male, nine female), mean age 36 (range 17-55) years and mean body-weight 132 (range 103-163) kg, who were all more than $40 \%$ in excess of their ideal weight by Metropolitan Life Insurance Company Criteria (range 41-194 kg) (Horowitz et al. 1985). All patients were Caucasian, non-smokers, on no medication, without known gastrointestinal disease and had been referred to the Weight Disorders Unit of the Royal Adelaide Hospital. Written informed consent was obtained in all cases and the study was approved by the Ethics Subcommittee of the Royal Adelaide Hospital.

\section{Study protocol}

The study design was a single-blind assessment of the effect of dexfenfluramine on gastric emptying in which each patient was their own control. Each subject was asked to have measurements of gastric emptying performed on three separate days. On the day immediately before the first gastric emptying test each subject took one placebo capsule morning (07.30 hours) and evening (19.30 hours). On the day of the first gastric emptying measurement one placebo capsule was taken at 07.30 hours. Each subject was then asked to take one $15 \mathrm{mg}$ capsule of dexfenfluramine (Adifax, Isomeride; Servier Laboratories Pty Ltd, Gidy, France) morning ( 07.30 hours) and evening (19.30 hours) for $29 \mathrm{~d}$ and the first capsule was taken on the evening after the first gastric emptying measurement. On days 5 and 29 after the commencement of dexfenfluramine, further measurements of gastric emptying were made after administration of $15 \mathrm{mg}$ dexfenfluramine at 07.30 hours. Each gastric emptying test was performed at 10.30 hours after the subject had fasted from 24.00 hours the previous day.

Drug compliance was assessed by tablet counts. On the day of each gastric emptying measurement the patient's body-weight was measured on the same scale. Each subject was asked to notify the investigators immediately of the occurrence of any possible adverse events during the study period and on each study day patients were asked to respond to the following question: 'Have you been aware of any unusual experience or feelings, whilst taking the tablets?' and responses were noted.

\section{Assessment of gastrointestinal symptoms}

Before the performance of each gastric emptying test, gastrointestinal symptoms were assessed by a standard questionnaire (Horowitz et al. 1987). 'Gastric' symptoms (anorexia, 
Table 1. Effect of dexfenfluramine $15 \mathrm{mg}$ twice daily on gastrointestinal symptoms in obese subjects

(Median values and ranges shown in parentheses)

\begin{tabular}{lccc} 
& & Dexfenfluramine \\
No. of subjects ... & Placebo & Day 5 & Day 29 \\
11 & 11 & 9 \\
\hline 'Oesophageal' score* & $1(0-6)$ & $0(0-3)$ & $0(0-3)$ \\
'Gastric' score* & $1(0-7)$ & $2(0-7)$ & $1(0-8)$ \\
Total score & $3(0-12)$ & $2(0-10)$ & $1(0-8)$ \\
No. of bowel actions/week & $7(2-14)$ & $10(7-28)$ & $10(7-25)$ \\
\hline
\end{tabular}

* For details, see below.

nausea, early satiety, upper abdominal discomfort or distention, vomiting, abdominal pain) and 'oesophageal' symptoms (dysphagia, heartburn and acid regurgitation) were scored according to the following scheme: 0 none, 1 mild (symptom could be ignored if the patient did not think about it), 2 moderate (symptom could not be ignored, but did not influence daily activities), 3 severe (symptom influenced daily activities). The maximum possible total score for the 'gastric' symptoms was therefore 18 and for the 'oesophageal' symptoms was 9. The number of bowel actions each week, the consistency of bowel actions and the presence or absence of nocturnal diarrhoea and faecal incontinence were also noted. The patient was considered to suffer from constipation if less than three spontaneous bowel actions occurred each week (Horowitz et al. 1987).

\section{Measurement of gastric emptying}

Details of this double-isotope test, which measures both solid and liquid gastric emptying simultaneously, have previously been published (Collins et al. 1983). The solid meal was $100 \mathrm{~g}$ cooked ground beef containing $1.0-1.5 \mathrm{mCi}{ }^{99 \mathrm{~m}} \mathrm{Tc}-$ sulphur colloid-chicken liver, labelled in vivo. The liquid meal was $150 \mathrm{ml} \mathrm{D}$-glucose $(100 \mathrm{~g} / \mathrm{l})$ in water labelled with $0.75-1 \mathrm{mCi}{ }^{113}$ In diethylene triamine penta-acetic acid (DTPA). The study was performed in the sitting position with the scintillation camera behind the patient. The patient initially ate the solid meal over a 5 min period and then immediately drank the D-glucose solution. Information was collected continuously from the onset of food ingestion and time zero was defined as the time of meal completion. Each study was continued for at least $2 \mathrm{~h}$.

For each frame of the study the radioactivity values in the gastric region-of-interest were corrected for patient movement, radionuclide decay, Compton scatter and gamma-ray (tissue) attenuation (Collins et al. 1983). The regions-of-interest for the proximal and distal stomach were also determined by a previously described method in which the proximal stomach is defined as the 'reservoir' area seen for at least the first few minutes after ingestion of the solid meal and a horizontal proximal-distal stomach dividing line is drawn immediately below this region (Collins et al. 1988).

From the activity-time curves of solid and liquid emptying (expressed as a percentage of the total meal remaining $v$. time) several variables were derived for subsequent statistical analysis. For the solid component these variables were the lag phase before any food left the stomach, the time for $25 \%$ emptying and the percentage of the meal remaining in the stomach at $100 \mathrm{~min}$. Some patients with delayed emptying did not reach $50 \%$ emptying for the total stomach during the study period and consequently this variable was not used for statistical analysis. For the liquid meal the percentage remaining in the stomach at $10 \mathrm{~min}$ after meal completion and the time for $50 \%$ emptying were obtained. The percentage of 

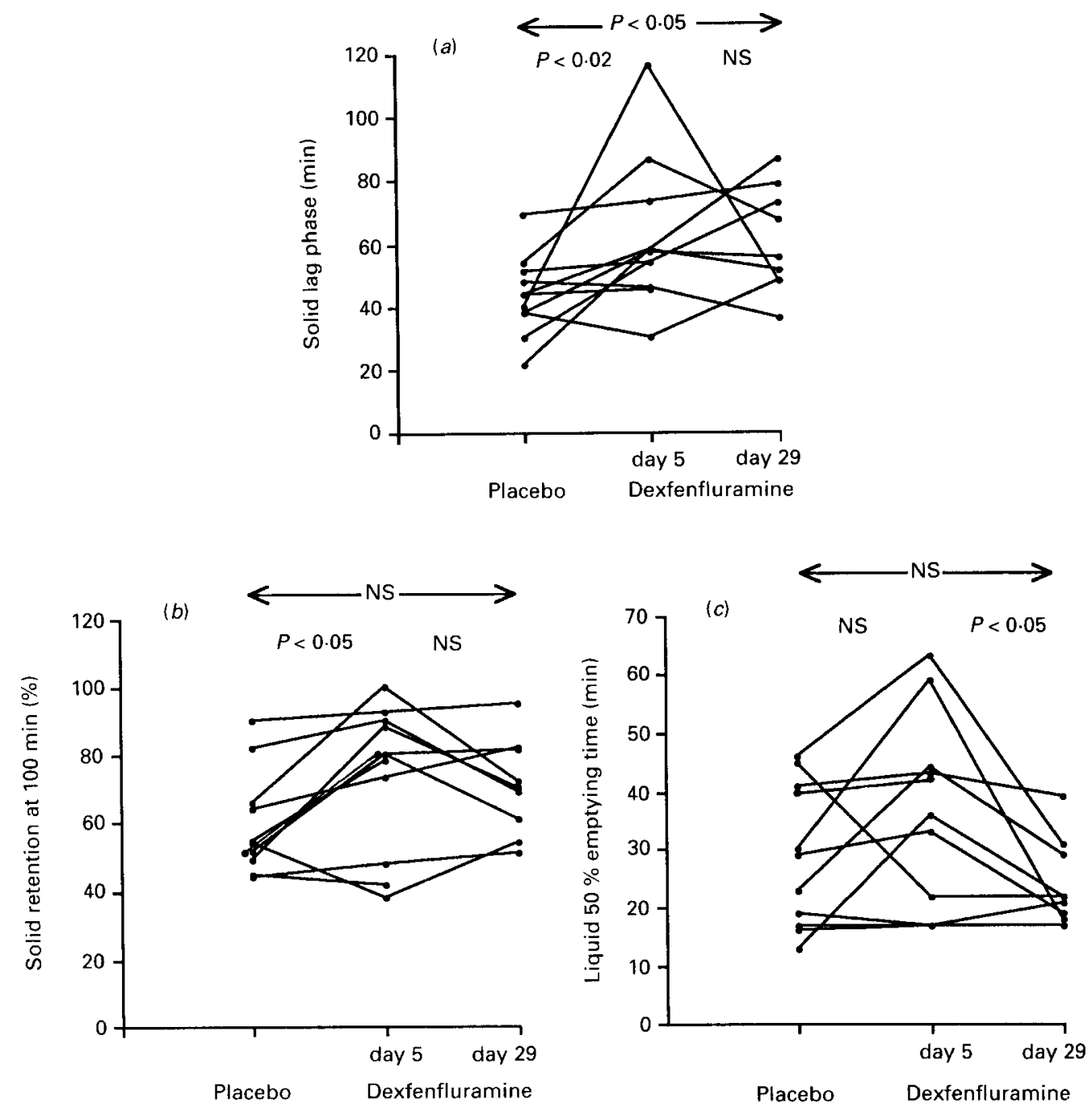

Fig. 1. Effect of dexfenfluramine ( $15 \mathrm{mg}$ twice daily) for 5 and $29 \mathrm{~d}$ on gastric emptying (from the total stomach) in obese subjects of a mixed solid-liquid meal for the: (a) solid lag phase, (b) percentage of the solid meal remaining at $100 \mathrm{~min}$, (c) $50 \%$ emptying time for the liquid meal. For details of procedures, see p. 448 . NS, not significant.

the liquid meal remaining at 10 min was used as an index of the early phase of gastric emptying (Horowitz et al. 1987). The time for $50 \%$ of the meal to empty from the proximal stomach was calculated for the solid meal and for the liquid meal (Collins et al. 1988).

\section{Statistical analysis}

Data were evaluated using the Wilcoxon matched-pairs signed-ranks test. A value of $P<0.05$ was considered significant in all analyses. Median values and ranges are reported in the text. 


\section{RESULTS}

All eleven patients underwent the first two gastric emptying measurements, but only nine of the eleven subjects attended for the third gastric emptying test. Telephone contact confirmed that the two dropouts did not withdraw because of side-effects and the remaining nine patients were assessed as being compliant with medication.

There was a slight, but significant decrease in body-weight between the day of the placebo test and day 29 (median 131 (range 103-163) kg v. 130 (range 99-162) kg, $P=$ 0.004).

Six patients reported that they were less hungry and five reported excessive tiredness. There was no significant difference in gastrointestinal symptoms between the three study days (Table 1) although on dexfenfluramine there was a non-significant trend $(P=0 \cdot 12)$ towards an increased frequency of bowel actions each week. Otherwise no adverse events were observed.

Gastric emptying of the solid meal was slower than that of the liquid meal and was characterized by an initial lag phase, before food left the stomach, which was followed by an emptying phase that usually approximated a linear pattern. The emptying curve for liquid was non-linear, with a slope that decreased with time and usually approximated a mono-exponential pattern (Collins et al. 1983). Treatment with dexfenfluramine was associated with a significant slowing of gastric emptying of the solid meal. At $5 \mathrm{~d}$ the lag phase $(P=0.018)$, the percentage remaining at $100 \mathrm{~min}(P=0.024)$ and the time taken for $25 \%$ emptying $(P=0.01)$ were greater than the placebo. On day 29 the lag phase was significantly prolonged $(P=0.04)$ compared with the placebo, but the trends for changes in the percentage of the meal remaining at $100 \mathrm{~min}$ and the time for $25 \%$ emptying did not quite reach statistical significance $(P=0.07$ for both). There was no significant difference in variables for solid emptying on day 5 compared with day 29. Dexfenfluramine had no significant effect on variables of liquid emptying, although on day 5 the $50 \%$ emptying time for the liquid meal was slower than that for the placebo in eight of the eleven subjects and identical in one subject $(P=0 \cdot 36)$, and the percentage retention at $10 \mathrm{~min}$ was also greater than that with the placebo in eight subjects $(P=0.076)$. Gastric emptying of liquid $(50 \%$ emptying time) was, however, faster $(P=0 \cdot 04)$ on day 29 compared with day 5 . These results are summarized in Table 2 and Fig. 1 .

On the placebo test the proximal stomach $50 \%$ emptying times for the solid and liquid meals correlated directly with the amount of the solid meal remaining at 100 min $(r 0.70$, $P<0.05)$ and the liquid $50 \%$ emptying time $(r 0.67, P<0.05)$ respectively. The $50 \%$ emptying time for the proximal stomach for the solid meal was slower on day $5(P=0.002)$ and on day $29(P=0.008)$ compared with placebo (Fig. 2). Dexfenfluramine had no significant effect on the proximal stomach $50 \%$ emptying time for the liquid meal. These results are summarized in Table 1 and Figs 1 and 2.

There was no significant correlation between gastric emptying and gastrointestinal symptoms.

\section{DISCUSSION}

It seems likely that the long-term regulation of food intake is mediated partly through complex neural and hormonal reflexes resulting from the presence of food in the gastrointestinal tract. The gastric distention theory of post-prandial satiety emphasizes the importance of peripheral factors in appetite regulation and is based on the close association between satiety, stomach distention and the cessation of eating (Gibbs \& Smith, 1978). Gastric distention is dependent on the rate of ingestion of food, intragastric pressure and the rate of gastric emptying. It is of interest that several agents which retard gastric 
Table 2. Effect of dexfenfluramine $15 \mathrm{mg}$ twice daily on gastric emptying in obese subjects (Median values and ranges shown in parentheses)

\begin{tabular}{|c|c|c|c|c|c|c|}
\hline \multirow{3}{*}{ No. of subjects.. } & & & \multicolumn{4}{|c|}{ Dexfenfluramine } \\
\hline & \multicolumn{2}{|c|}{$\begin{array}{c}\text { Placebo } \\
11\end{array}$} & \multicolumn{2}{|c|}{$\begin{array}{c}\text { Day } 5 \\
11\end{array}$} & \multicolumn{2}{|c|}{$\begin{array}{l}\text { Day } 29 \\
9\end{array}$} \\
\hline & Median & Range & Median & Range & Median & Range \\
\hline \multicolumn{7}{|l|}{ Total stomach: } \\
\hline \multicolumn{7}{|l|}{ Solid } \\
\hline Lag phase (min) & 44 & $(21-69)$ & $57^{*}$ & $(30-116)$ & $55^{*}$ & $(36-86)$ \\
\hline Retention at $100 \mathrm{~min}(\%)$ & 54 & $(44-90)$ & $80^{*}$ & $(38-100)$ & 70 & $(51-95)$ \\
\hline $25 \%$ emptying time (min) & 75 & $(48-123)$ & $114^{*}$ & $(60-140)$ & 86 & $(66-142)$ \\
\hline \multicolumn{7}{|l|}{ Liquid } \\
\hline Retention at $10 \min (\%)$ & 79 & $(60-95)$ & 91 & $(64-100)$ & 76 & $(58-90)$ \\
\hline $50 \%$ emptying time (min) & 29 & $(13-46)$ & 36 & $(17-63)$ & $22 \dagger$ & $(17-39)$ \\
\hline \multicolumn{7}{|l|}{ Proximal stomach: } \\
\hline $\begin{array}{l}\text { Solid } 50 \% \text { emptying time } \\
\text { (min) }\end{array}$ & 41 & $(2-104)$ & $67^{* *}$ & $(6-138)$ & $62^{* *}$ & $(27-95)$ \\
\hline $\begin{array}{l}\text { Liquid } 50 \% \text { emptying time } \\
\text { (min) }\end{array}$ & 3 & $(0-23)$ & 2 & $(0-24)$ & 4 & $(1-10)$ \\
\hline
\end{tabular}

Median values were significantly different from those for subjects when given the placebo: ${ }^{*} P<0 \cdot 05,{ }^{* *} P<$ $0 \cdot 01$.

Median values were significantly different from those of day 5 of treatment: $\uparrow P<0.05$.

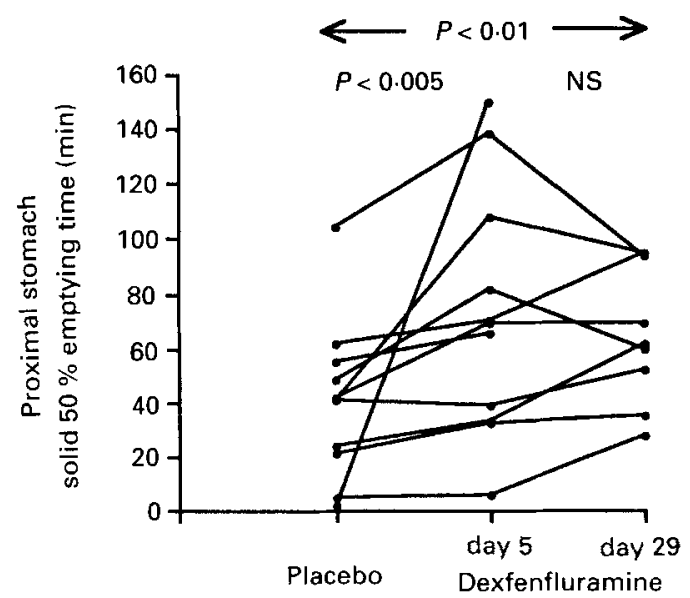

Fig. 2. Effect of dexfenfluramine ( $15 \mathrm{mg}$ twice daily) for 5 and $29 \mathrm{~d}$ on the time-interval for $50 \%$ of the solid meal to empty from the proximal stomach in obese subjects. For details of procedures, see p. 448 . NS, not significant.

emptying after acute administration, such as salbutamol (Rees et al. 1980), L-DOPA (Berkowitz \& McCallum, 1980), and cholecystokinin octapeptide (Liddle et al. 1986) have been reported to inhibit feeding.

Dexfenfluramine has many physiological effects which could underlie its action on food intake and body-weight. These include gastric inhibition, central anorectic effects and alterations in glucose and lipid metabolism (Booth et al. 1986; Even \& Nicolaidis, 1986; Rowland \& Carlton, 1986 b). There is at present a lack of consensus concerning the relative importance of these mechanisms. Our previous study supports a role for inhibition of 
gastric emptying in the fenfluramine-induced suppression of feeding observed after acute administration of this drug (Horowitz et al. 1985). The slowing of gastric emptying may also be relevant to the interpretation of some of the metabolic effects of fenfluramine on lipid and carbohydrate metabolism (Stunkard, 1981; Even \& Nicolaidis, 1986; Rowland \& Carlton, 1986 b).

Dexfenfluramine inhibited gastric emptying of a solid meal and, in contrast to the effect of DL-fenfluramine in the rat (Rowland \& Carlton, 1984), this action was maintained for at least $29 \mathrm{~d}$. The slower emptying of the solid meal reflected a prolongation of the lag phase before solid food emptied from the stomach which, at least in part, was demonstrated to be due to a slower redistribution of solid food from proximal to distal stomach. This effect may be mediated by a reduction in fundal tone, as suggested by Robinson et al. (1986), but the possibility of an inhibition of the mixing function of the antrum, or changes in pyloric or duodenal motility (Houghton et al. 1988) have not been excluded. While the magnitude of the delay in solid emptying was not large (approximately a $25 \%$ prolongation of the lag phase), this may correspond to the 10-20\% reduction of energy intake typically reported in humans (Stunkard, 1981).

The absence of a significant effect of dexfenfluramine on gastric emptying of liquid (particularly at $5 \mathrm{~d}$ ) may reflect a type 2 error (i.e. due to the relatively small number of subjects that we studied) or the use of a liquid meal of relatively low energy density (Collins et al.1983). Previous studies in animals have suggested that DL-fenfluramine may produce greater inhibition of gastric emptying of solid, compared with liquid meals (Rowland \& Carlton, $1986 \mathrm{~b}$ ). It is, of course, possible that higher doses of dexfenfluramine may modify liquid emptying and there is some evidence that plasma concentrations of fenfluramine correlate with weight loss (Innes et al. 1977; Rowland \& Carlton, 1986 b).

The effect of dexfenfluramine on gastric emptying is likely to be mediated by effects on serotonergic mechanisms (Pollock \& Rowland, 1981), but it is not clear which of the three types of serotonin receptor $\left(5-\mathrm{HT}_{1}, 5-\mathrm{HT}_{2}, 5-\mathrm{HT}_{3}\right)$ that have been characterized (Richardson \& Engel, 1986) is important for this effect. Since dexfenfluramine causes the release of serotonin (5-HT) it will have effects on all 5-HT receptors. Previous studies have suggested that central $5-\mathrm{HT}_{2}$ receptors are not involved in mediating the central anorectic effect of dexfenfluramine, but that central $5-\mathrm{HT}_{1}$ receptors are of importance (Gibbs \& Smith, 1978; Barone et al. 1985). The low affinity 5-HT-M receptors located at excitatory receptors on peripheral neurones, which have recently been called 5- $\mathrm{HT}_{3}$ receptors, occur in the enteric nervous system where they control the release of substance $\mathrm{P}$, which activates the smooth muscle cells of the gut wall (Richardson \& Engel, 1986). Information obtained in animal and human studies indicates that $5-\mathrm{HT}_{3}$ receptors may play an important role in the regulation of gastrointestinal motility (Fozard, 1984; Buchheit et al. 1985; Costall et al. 1986; Akkermans et al. 1988). The selective 5-HT 3 receptor antagonists ICS 205-930 (Buchheit et al. 1985; Akkermans et al. 1988), MDL 7222 (Fozard, 1984) and GR 38032 (Costall et al. 1986) increase the rate of gastric emptying in animals or humans, or both. There is indirect evidence that fenfluramine releases 5-HT from the gut, because its administration causes ileal contractions which can be blocked by 5-HT antagonists (Mottram \& Patel, 1979), although gastric levels of 5-HT are apparently not depleted by fenfluramine (Costa et al. 1971). An explanation for the effect of dexfenfluramine on gastric emptying is, therefore, direct stimulation of 5- $\mathrm{HT}_{3}$ receptors in the stomach, but an action on central nervous system control mechanisms is also possible. To date there are apparently no studies of the effects of 5-HT antagonists, either central or peripheral, on gastric inhibition due to fenfluramine to clarify this postulate.

Our study supports the results of other studies demonstrating that dexfenfluramine is generally well tolerated and induces weight loss (Guy-Grand et al. 1989; Finer et al. 1985, 1987). The symptoms of diarrhoea and tiredness observed by some subjects were mild, but 
may have been related to the use of the drug (Finer et al. 1985, 1987). Similarly, although we were unable to demonstrate a significant correlation, symptoms such as nausea may relate to delayed gastric emptying. There appears to be a lower prevalence of side-effects with dexfenfluramine compared with the racemic mixture, probably because after a standard dose plasma concentrations of L-fenfluramine are more variable than dexfenfluramine (Finer et al. 1987). Steady-state concentrations of dexfenfluramine are usually achieved in normal volunteers within $4 \mathrm{~d}$ and are not dependent on body-weight, and the absence of L-fenfluramine does not significantly modify the kinetic variables of dexfenfluramine, or its active metabolite D-norfenfluramine (Caccia et al. 1982). Consequently the dosage of $30 \mathrm{mg}$ D-fenfluramine/d used in our study is no greater than the quantity delivered by the lowest recommended dose of DL-fenfluramine (Innes et al. 1977; Stunkard, 1981; Finer et al. 1985).

The weight loss produced by DL-fenfluramine (and probably also dexfenfluramine (Finer et al. 1987; Guy-Grand et al. 1989)) in humans, does not continue indefinitely and, characteristically, at about 6 months, a steady-state body-weight is reached, some $10 \mathrm{~kg}$ below the initial weight (Innes et al. 1977; Stunkard, 1981). This plateau in weight loss has been postulated to reflect a metabolic adaptation to the lower weight, or tolerance to the effect of the drug (Stunkard, 1981), but this problem remains unresolved as there are virtually no long-term studies of the mechanisms of long-term anorexia from fenfluramine, partly due to the rapid development of tolerance in many animal models (Rowland \& Carlton, 1986 b). While we did not observe any difference in the effect of dexfenfluramine on gastric emptying of the solid meal at $5 \mathrm{~d}$ compared with $29 \mathrm{~d}$, the difference in liquid emptying indicates that more prolonged studies are required to confirm that the effect of dexfenfluramine on gastric emptying is maintained. The demonstration in the present study that the effect of dexfenfluramine in slowing gastric emptying of solid food is sustained for $29 \mathrm{~d}$, however, suggests that retardation of gastric emptying may contribute to the efficacy of dexfenfluramine in the treatment of obesity.

The authors wish to thank Dr Amanda Rose for her invaluable assistance. This study was supported by IRIS: Institut de Recherches Internationales Servier. This work was presented in abstract form at the 90th Annual Meeting of the American Gastroenterological Association, Washington DC, 13-19 May 1989.

\section{REFERENCES}

Akkermans, L. M. A., Vos, A., Hoekstra, A., Roelofs, J. M. M. \& Horowitz, M. (1988). The effect of ICS $205-$ 930 (a specific 5- $\mathrm{HT}_{33}$ receptor antagonist) on gastric emptying of a solid meal in normal subjects. Gut 29 , 1249-1252.

Barone, D., Luzzani, F., Assandri, A., Galliani, G., Mennini, T. \& Garattini, S. (1985). In vivo stereospecific $\left[{ }^{3} \mathrm{H}\right]$ spiperone binding in rat brain: characteristics, regional distribution, kinctics and pharmacological properties. European Journal of Pharmacology 116, 63-74.

Berkowitz, D. M. \& McCallum, R. W. (1980). Interaction of levodopa and metoclopramide on gastric emptying. Clinical Pharmacology and Therapeutics 27, 414-420.

Blundell. J. E. \& Leshem, M. B. (1974). Central action of anorexic agents: effects of amphetamine and fenfluramine in rats with lateral hypothalamic lesions. European Journal of Pharmacology 28, 81-89.

Booth, D. A., Gibson, E. L. \& Baker, B. J. (1986). Gastromotor mechanism of fenfluramine anorexia. Appetile 7. Suppl., 5769.

Buchheit, K. H., Engel. G., Mutschler, E. \& Richardson, B. (1985). Study of the coniractile effect of 5hydroxytryptamine $(5-\mathrm{HT})$ in the isolated longitudinal muscle strip from guinea-pig ileum. NanninSchmedebergs Archives of Phamacology 329, 3641.

Caccia, S., Ballabio, M., Guiso. G., Rochetti, M. \& Garattini, S. (1982). Special differences in the kinetics and metabolism of fenfluramine isomers. Archives Internationales de Pharmacodynamie et de Therapie 258. 15-28.

Collins, P. J., Horowitz, M. \& Chatterton, B. E. (1988). Proximal, distal and total stomach emptying of a digestible solid meal in normal subjects. British Journal of Radiology 61, 12-18.

Collins. P. J., Horowitz, M., Cook, D. J., Harding, P. E. \& Shearman, D. J. C. (1983). Gastric emptying in normal subjects - a reproducible technique using a single scintillation camera and computer system. Gut 24, 1117-1125. 
Consolo, S., Ladinsky, H., Forloni, G. L., Tirelli, A. S. \& Garattini, S. (1980). Comparison of the effects of the stereoisomers of fenfluramine on the acetylcholine content of rat striatum, hippocampus and nucleus accumbens. Journal of Pharmacy and Pharmacology 32, 201-203.

Costa, E., Groppetti, A. \& Revuetta, A. (1971). Action of fenfluramine on monoamine stores of rat tissue. British Journal of Pharmacology 41, 57-64.

Costall, B., Kelly, M. E., Naylor, R. J., Tan, C. C. W. \& Tattersall, F. D. (1986). 5-Hydroxytryptamine Mreceptor antagonism in the hypothalamus facilitates gastric emptying in the guinea-pig. Neuropharmacology 25 , $1293-1296$.

Davies, R. F., Rossi, J., Panksepp, J., Bean, N. J. \& Zolovick, A. J. (1983). Fenfluramine anorexia : a peripheral locus of action. Physiology and Behaviour 30, 723-730.

Even, P. \& Nicolaidis, S. (1986). Dextrofenfluramine increases energy cost of muscular effect. Pharmacology, Biochemistry and Behaviour 24, 647-656.

Finer, N., Craddock, D., Lavielle, R. \& Keen, H. (1985). Dextrofenfluramine in refractory obesity. Current Therapeutic Research 38, 847-854.

Finer, N., Craddock, D., Lavielle, R. \& Keen, H. (1987). Prolonged weight loss with dexfenfluramine treatment in obese patients. Diabète et Métabolisme 13, 598-602.

Fozard, J. R. (1984). MDL 7222: a potent and highly selective antagonist at neuronal 5-hydroxytryptamine receptors. Naunyn-Schmiedebergs Archives of Pharmacology 326, $36-44$.

Garattini, S., Caccia, S., Mennini, T., Samanin, R., Consolo, S. \& Ladinsky, H. (1979). Biochemical pharmacology of the anorectic drug fenfluramine: a review. Current Medical Research Opinion 6, 15-27.

Garattini, S., Mennini, T. \& Samanin, R. (1987). From fenfluramine racemate to D-fenfluramine. Specificity and potency of the effects on the serotoninergic system and food intake. In Human Obesity, vol. 499, pp., 156-166 [R. J. Wurtman and J. J. Wurtman, editors]. New York: New York Academy of Sciences.

Gibbs, J. \& Smith, G. P. (1978). The gut and preabsorptive satiety. Acta Hepatologica-Gastroenterologica 35, $413-416$

Guy-Grand, B., Apselbaum, M., Crepaldi, G., Gries, A., Lefevre, P. \& Turner, P. (1989). International trial of long-term dexfenfluramine in obesity. Lancet ii, 1142-1144.

Hirsch, J. A., Goldberg, S. \& Wurtman, R. J. (1982). Effect of (+) or (-)-enantiomers of fenfluramine or norfenfluramine on nutrient selection by rats. Journal of Pharmacy and Pharmacology 34, 18-21.

Horowitz, M., Collins, P. J., Tuckwell, V., Vernon-Roberts, J. \& Shearman, D. J. C. (1985). Fenfluramine delays gastric emptying of solid food. British Journal of Clinical Pharmacology 19, 849-851.

Horowitz, M., Maddox, A., Harding, P. E., Maddern, G. J., Chatterton, B. E., Wishart, J. \& Shearman, D. J. C. (1987). Effect of cisapride on gastric and esophageal emptying in insulin-dependent diabetes mellitus Gastroenterology 92, 1899-1907.

Houghton, L. A., Read, N. W., Heddle, R., Horowitz, M., Collins, P. J., Chatterton, B. \& Dent, J. (1988). The relationship of the motor activity of the antrum, pylorus and duodenum to gastric emptying of a solid-liquid mixed meal. Gastroenterology 94, 12851291.

Innes, J. A., Watson, M. L., Ford, M. J., Munro, J. F., Stodolant, M. C. \& Campbell, D. B. (1977). Plasma fenfluramine levels, weight loss and side effects. British Medical Journal ii, 13221325.

LeDouarec, J. D., Schmitt, H. \& Laubie, M. (1966). Etude pharmacologique de la fenfluramine et de ses isomères optiques. Archives Internationales de Pharmacodynamie et de Thérapie 161, 206-232.

Liddle, R. A., Morita, E. T., Conrad, C. K. \& Williams, J. A. (1986). Regulation of gastric emptying in humans by cholecystokinin. Journal of Clinical Investigations 77, 992996.

Mottram, D. R. \& Patel, R. J. (1979). Peripheral effects of fenfluramine mediatcd via the releasc of 5 hydroxytryptamine. General Pharmacology $10,441444$.

Pollock, J. D. \& Rowland, N. (1981). Peripherally administered serotonin decreases food intake in rats. Pharmacology, Biochemistry and Behaviour 15, 179-183.

Rees, W. R., Clark, R. A., Holdsworth, C. D., Barber, D. C. \& Howlett, P. J. (1980). The effect of $\beta$ adenoreceptor agonists and antagonists on gastric emptying in man. British Journal of Clinical Pharmacology 10, 551-554.

Richardson, B. P. \& Engel, G. (1986). The pharmacology and function of 5-HT receptors. TINS 9, 424428.

Robinson, P. H., Moran, T. H. \& McHugh, P. R. (1986). The inhibition of gastric emptying and feeding in fenfluramine. American Journal of Physiology 250, R764-R799.

Rowland, N. E. \& Carlton, J. (1984). Inhibition of gastric emptying by peripheral and central fenfluramine in rats correlation with anorexia. Life Sciences 34, 2495-2499.

Rowland, N. E. \& Carlton, J. (1986a). Tolerance to fenfluramine anorexia : fact or fiction? Appetite 7, Suppl.. $71 \ldots 83$.

Rowland, N. E. \& Carlton, J. (1986b). Neurobiology of an anorectic drug: fenfluramine. Progress in Neurobiology 27, 13-62.

Rowland, N. E. \& Carlton, J. (1986c). Effects of fenfluramine on food intake, body weight, gastric emptying and brain monoamines in Syrian hamsters. Brain Research Bulletin 17, 575-581.

Stunkard, A. J. (1981). Anorectic agents: a theory of action and lack of tolerance in a clinical trial. In Anorectic Agents: Mechanisms of Action and Tolerance, pp. 191-209 [S. Garattini and R. Samanin, editors]. New York: Raven Press. 